\author{
Dorota MilanowsKa ${ }^{1}$
}

\title{
Wybrane metody systematyzacji prawodawstwa Unii Europejskiej z uwzględnieniem aktów prawnych z zakresu prawa rolnego
}

\section{Uproszczenie i systematyzacja prawodawstwa unijnego}

Proces uproszczenia wtórnego prawodawstwa wspólnotowego (acquis communautaire) polegający na usystematyzowaniu i ograniczeniu liczby aktów prawnych i przepisów prawnych oraz uczynieniu regulacji prawnych bardziej przystępnymi rozpoczęto w latach 90. XX w. W 1992 r. Rada Europejska w Edynburgu wyraziła konieczność uproszczenia acquis communautaire, co zostało rozwinięte w porozumieniach międzyinstytucjonalnych z lat 1994, 2001 i 2003, w których Parlament Europejski, Rada i Komisja zobowiązały się do stosowania określonych metod systematyzacji prawodawstwa Unii oraz do sporządzania aktów prawnych przy uwzględnieniu wspólnych dla tych trzech instytucji zasad techniki prawodawczej. Metody te są istotnym elementem procesu uproszczenia wtórnego prawodawstwa Unii, zapowiedzianego także w szeregu komunikatach Komisji. ${ }^{2}$ Ocena postępu w pracach nad upraszczaniem prawodawstwa oraz planowane przyszłe działania Komisja zawiera natomiast w sprawozdaniach i komunikatach do Parlamentu i Ra$\mathrm{dy} \cdot{ }^{3}$

$1 \quad$ Autorka jest pracownikiem Komisji Europejskiej. Poglądy wyrażone w artykule są wyłącznie poglądami autorki i nie wiążą Komisji Europejskiej.

2 Proces uproszczenia prawodawstwa wspólnotowego rozpoczęto pod koniec lat 90. XX w. Obszerny program w tym zakresie zawierał komunikat Komisji: Updating and simplifying the Community acquis (Uaktualizacja i uproszczenie dorobku prawnego Wspólnoty), COM(2003) 71 wersja ostateczna. Zob. także sprawozdanie Komisji do Rady Europejskiej w Sztokholmie: Improving and symplifying the regulatory environment (Ulepszenie i uproszczenie otoczenia regulacyjnego), COM(2001) 130 wersja ostateczna.

3 Zob. następujące komunikaty Komisji: Realizacja działania ramowego: Aktualizacja i uproszczenie prawa wspólnotowego, COM(2004) 432 wersja ostateczna; Realizacja wspólnotowego programu lizbońskiego: Strategia w zakresie uproszczenia otoczenia regulacyjnego, $\operatorname{COM(2005)} 535$ wersja ostateczna; Strategiczny przegląd procesu lepszego stanowienia prawa w Unii Europejskiej, COM(2006) 689, wersja ostateczna; sprawozdanie Komisji: Lepsze stanowienie prawa, 2004 COM(2005) 98 oraz dokument roboczy Komisji: Pierwsze sprawozdanie z realizacji strategii uproszczenia otoczenia regulacyjnego, $\operatorname{COM}(2006) 690$ wersja ostateczna. 
Pierwsze porozumienie zawarte 20 grudnia 1994 r. dotyczy szybszej metody pracy nad urzędową kodyfikacją tekstów prawnych. ${ }^{4}$ Kolejne porozumienie zawarte w 2001 r. z dnia 28 listopada 2001 r. w sprawie bardziej uporządkowanego wykorzystania techniki przekształcania aktów prawnych przewidywało przygotowywanie tzw. przekształceń aktów prawnych ${ }^{5}$ (omówienie obu tych porozumień nastąpi w dalszej części niniejszego artykułu). Najnowszym dokumentem dotyczącym instrumentów służących usystematyzowaniu prawodawstwa unijnego jest porozumienie międzyinstytucjonalne z $2003 \mathrm{r}$. w sprawie lepszego stanowienia prawa. ${ }^{6} \mathrm{Na}$ mocy tego porozumienia Parlament Europejski, Rada i Komisja zobowiązały się do poprawy jakości prawodawstwa Unii poprzez szereg inicjatyw i działań podejmowanych przy poszanowaniu zasad proporcjonalności, pomocniczości, pewności prawa i demokracji. Wśród działań, do których zobowiązały się trzy instytucje wymieniono lepszą koordynację całego procesu ustawodawczego i zapewnienie jego przejrzystości poprzez przygotowywanie szczegółowego harmonogramu prac oraz wzajemne informowanie się instytucji o postępach danego etapu prac legislacyjnych. Komisja zobowiązała się do pełnego uzasadnienia wybranej podstawy prawnej oraz danego instrumentu prawodawczego, tj. rozporządzenia lub dyrektywy, najbardziej adekwatnego dla regulacji prawnych $\mathrm{w}$ danej dziedzinie, oraz do składania sprawozdań z postępów prac nad wnioskami ustawodawczymi, co ma spełnić wymóg lepszego informowania odbiorców. Punkty 25.-30. porozumienia z 2003 r. dotyczyły poprawy jakości prawodawstwa poprzez m.in. wymóg, że unijne akty prawne mają być jasne, proste i skuteczne, a ich formalne uchwalenie musi być poprzedzone konsultacjami prowadzonymi na poziomie trzech instytucji, których wyniki mają być ogólnie dostępne.

W porozumieniu podkreślono, że podniesienie jakości prawodawstwa Unii i uczynienie go bardziej przystępnym dla adresatów uzależnione jest także od działań organów państw członkowskich transponujących postanowienia prawa unijnego do krajowych porządków prawnych. Porozumienie reguluje kwestie poprawy transpozycji i stosowania prawa Unii, ustanawiając maksymalny 2-letni termin transpozycji dyrektyw z odpowiednią kontrolą ze strony Komisji. Systematyzacja prawodawstwa jest przedmiotem pkt. 35. i 36. porozumienia, które dotyczą procesu uproszczenia i zredukowania liczby aktów prawnych, wpisanego w wieloletni plan prac Komisji. Zgodnie z postanowieniami porozumienia uaktualnienie i zredukowanie objętości prawodawstwa dokonane ma być poprzez uchylanie aktów prawnych, przygotowywanie tekstów jednolitych oraz przekształceń. Uproszczenie prawodawstwa ma natomiast być osiągnięte dzięki technice przekształcenia aktów obecnie 
obowiązujących oraz poprzez przedkładanie nowych wniosków ustawodawczych w wybranych przez Komisję dziedzinach.

Poniżej nastąpi przedstawienie trzech najważniejszych metod systematyzacji prawodawstwa unijnego, do których należą: sporządzanie wersji skonsolidowanych, tekstów jednolitych oraz przekształcanie aktów prawnych. Metody konsolidacji, ujednolicania i przekształcania stanowią trzy następujące po sobie etapy systematyzacji wtórnego prawa Unii. Przedstawienie pozostałych instrumentów, do których należą m.in.: sprostowanie błędu, uchylanie aktów prawnych i usuwanie aktów nieaktualnych wykracza natomiast poza zakres niniejszego artykułu. Wymienione metody systematyzacji prawodawstwa unijnego są uzupełniane przez szczegółowe wytyczne dotyczące techniki prawodawczej, mające zastosowanie w procesie redagowania aktów prawnych i formułowania przepisów przez Parlament Europejski, Radę i Komisję, zawarte w porozumieniu międzyinstytucjonalnym z dnia 22 grudnia 1998 r. w sprawie wspólnych wytycznych dotyczących jakości prawodawstwa wspólnotowego. ${ }^{7}$ Wytyczne te są, obok instrumentów systematyzacji prawodawstwa, drugim elementem niezbędnym do zapewnienia zrozumiałego i jasnego prawodawstwa Unii.

\section{Wersje skonsolidowane aktów prawnych}

Konsolidacja wtórnego prawodawstwa Unii jest instrumentem wyjściowym w procesie systematyzacji wtórnego prawodawstwa unijnego. Proces ten ma na celu zwiększenie przejrzystości prawa oraz umożliwienie uzyskania pełnego obrazu sytuacji prawnej w danej dziedzinie. Na szczycie w Edynburgu w 1992 r. Rada Europejska wprowadziła rozróżnienie pomiędzy „nieurzędową konsolidacją” aktów prawnych a „urzędowymi tekstami jednolitymi”" i w pkt. II 1) załącznika 3. do części A konkluzji stwierdziła, że obie procedury systematyzacji prawodawstwa mają przebiegać równolegle. „Nieurzędową konsolidację” Rada Europejska zdefiniowała jako połączenie w jeden tekst części aktów prawnych z danej dziedziny, dokonywane poza procesem ustawodawczym, które nie pociąga za sobą nabycia mocy prawnej przez nowo powstały tekst i pozostawia w mocy akty będące przedmiotem konsolidacji. „Urzędowy tekst jednolity” jest przedmiotem prac prowadzonych w ramach normalnej procedury ustawodawczej i pociąga za sobą uchylenie wszystkich zespolonych w nim aktów prawnych.

Konsolidacja jest procesem polegającym na zespoleniu w jednym tekście aktu pierwotnego i aktów go zmieniających. W ramach procesu konsolidacji nie wprowadza się do nowo powstałego tekstu tzw. zmian merytorycznych dotyczących treści 
przepisów prawnych z wyjątkiem tych wynikających z aktów zmieniających, których określone przepisy włączane są do wersji skonsolidowanej. W związku z tym, skonsolidowana wersja aktu prawnego nie posiada także własnych autonomicznych motywów uzasadniających wprowadzenie poszczególnych przepisów, a w jego początkowej części powtarzane są motywy pierwotnego aktu prawnego.

Na sporządzenie tekstu skonsolidowanego składa się sekwencja działań o charakterze technicznym, podejmowanych, w przeciwieństwie do tekstów jednolitych i przekształceń, poza procedurą ustawodawczą. Tekst powstały w wyniku prac konsolidacyjnych nie ma obowiązującej mocy prawnej: wszystkie zespolone w nim akty prawne, tj. akt pierwotny oraz późniejsze akty zmieniające i uchylające, zachowują swoje numery i pozostają nadal w mocy. Dlatego też wersja skonsolidowana nie powinna być przedmiotem odesłań w innych aktach prawnych. Skonsolidowana wersja aktu prawnego zawiera specjalne oznaczenia pozwalające zidentyfikować, jaki akt prawny wprowadził dane zmiany do aktu pierwotnego. Wersja skonsolidowana umieszczana jest na stronie dotyczącej danego aktu prawnego w internetowej bazie aktów prawnych EUR-Lex. ${ }^{9}$

Pierwszy obszerny etap prac konsolidacyjnych nad prawodawstwem wtórnym rozpoczęto w $1993 \mathrm{r}$. Organem odpowiedzialnym za sporządzanie tekstów skonsolidowanych jest Urząd Publikacji Unii Europejskiej, który w 1998 r. otrzymał oficjalne zlecenie przeprowadzenia procesu konsolidacji wtórnego prawodawstwa wspólnotowego. Pierwszy etap konsolidacji prawodawstwa został zakończony przez Urząd Publikacji w 2003 r., przed rozszerzeniem Unii o 10 krajów. Umożliwiło to udostępnienie skonsolidowanego prawodawstwa w bazie aktów prawnych EUR-Lex w 11 językach urzędowych. Jesienią 2004 r. Urząd Publikacji rozpoczął konsolidację aktów prawnych w tzw. nowych językach urzędowych, czyli językach państw, które przystąpiły do Unii Europejskiej w 2004 r., m.in. w języku polskim. Z ukończeniem tego etapu w 2007 r. skonsolidowane akty prawne dostępne były w 19 z 20 wówczas języków urzędowych (konsolidacja nie objęła języka maltańskiego). Na chwilę obecną Urząd zakończył praktycznie konsolidację prawa wtórnego w języku bułgarskim i rumuńskim, a konsolidacja prawodawstwa w języku maltańskim jest bardzo zaawansowana. Jeśli chodzi o nowy 24. język urzędowy - j. chorwacki, obecnie nadal trwają prace nad publikacją w tym języku prawodawstwa wtórnego Unii, a prace konsolidacyjne będą dokonywane na bieżąco.

Oprócz wspomnianych projektów konsolidacyjnych, które dla większości języków urzędowych Unii zostały już zakończone, Urząd Publikacji dokonuje bieżącej konsolidacji, tzn. stale sprawdza się, czy w Dzienniku Urzędowym Unii Euro-

Por. przykładowo wersje skonsolidowane rozporządzenia Rady (WE) nr 1698/2005 z dnia 20 września 2005 r. w sprawie wsparcia rozwoju obszarów wiejskich przez Europejski Fundusz Rolny na rzecz Rozwoju Obszarów Wiejskich (EFRROW), Dz.U. L 277 z 21.10.2005, s. 1, umieszczone na stronie dotyczącej tego aktu w internetowej bazie aktów prawnych EUR_Lex: http://eur-lex.europa.eu/en/index.htm 
pejskiej opublikowano akty zmieniające do aktów pierwotnych i, jeśli tak, dokonuje konsolidacji aktu pierwotnego poprzez włączanie do tekstu kolejnych zmian przepisów.

Teksty skonsolidowane mają ogromne znaczenie w procesie systematyzacji prawa Unii - są materiałem wyjściowym do przygotowania urzędowego tekstu jednolitego aktu prawnego.

\section{Teksty jednolite aktów prawnych}

Tekst jednolity (codification), w przeciwieństwie do wersji skonsolidowanej aktu prawnego, posiada status samodzielnego aktu prawnego, który, opatrzony nowym numerem, podlega publikacji w Dzienniku Urzędowym Unii Europejskiej i uzyskuje moc prawną. Ujednolicanie tekstów aktów prawnych jest procesem polegającym na większej ingerencji w tekst aktu prawnego niż konsolidacja i polega na zgrupowaniu w jednym tekście pierwotnego aktu prawnego i wszystkich późniejszych zmian aktu wprowadzonych do momentu publikacji tekstu jednolitego oraz obejmuje dodatkową interwencję w tekst ujednolicany polegającą na usuwaniu przepisów nieaktualnych, dostosowaniu terminologii specjalistycznej i prawnej $\mathrm{w}$ celu jej ujednolicenia w całym akcie. Tekst aktu prawnego powstałego w wyniku ujednolicenia oraz podstawa prawna są identyczne z tytułem i podstawą prawną pierwotnego aktu prawnego. Tekst jednolity zawiera także powtórzone motywy z aktu pierwotnego i aktów zmieniających, do których mogą być dołączone także własne autonomiczne motywy uzasadniające wprowadzenie do tekstu określonych zmian. Dodaje się także motyw standardowy, wyjaśniający, że w przypadku danego aktu chodzi o tekst jednolity aktu już istniejącego. ${ }^{10}$

Przygotowanie tekstu jednolitego polega na prowadzeniu bardziej pogłębionych prac nad wcześniej sporządzoną wersją skonsolidowaną aktu prawnego. W wyniku ujednolicenia aktu wszystkie akty prawne zgrupowane w nowo powstałym tekście jednolitym zostają uchylone i zastąpione nowym aktem prawnym. W praktyce można wyróżnić ,pionowe” i ,poziome” ujednolicanie aktu. Ujednolicenie ,pionowe" obejmuje akt pierwotny i wszystkie akty go zmieniające. Rzadziej występujące w praktyce ujednolicenie ,poziome” obejmuje większą liczbę aktów z danej dziedziny oraz akty je zmieniające. ${ }^{11}$

Istotnym wyróżnikiem tekstów jednolitych jest ich przyjmowanie w ramach procedury ustawodawczej przewidzianej dla danej dziedziny przez Traktat o funk-

10 Por. np. rozporządzenie wykonawcze Komisji (UE) nr 1273/2011 z dnia 7 grudnia 2011 r. otwierające niektóre kontyngenty celne na przywóz ryżu i ryżu łamanego oraz stanowiące o administrowaniu nimi, Dz.U. L 325 z 8.12.2011, s. 6; rozporządzenie wykonawcze Komisji (UE) nr 29/2012 z dnia 13 stycznia 2012 r. w sprawie norm handlowych w odniesieniu do oliwy z oliwek, Dz.U. L 12 z 14.1.2012, s. 14.

11 Por. Stefania Dragone, La codification communautaire: techniques et procédures, „Revue du Marché Unique Européen" $1998, n^{\circ} 1$, s. 77. 
cjonowaniu Unii Europejskiej (TFUE). Proces przygotowywania tekstów jednolitych aktów prawnych rozpoczynany jest przez Służbę Prawną Komisji, która, we współpracy z daną merytoryczną Dyrekcją Generalną Komisji, analizuje tekst mający być przedmiotem wniosku ustawodawczego przedłożonego Parlamentowi Europejskiemu i Radzie. Następnie wniosek jest rozpatrywany w ramach procedury ustawodawczej, obecnie zwykłej lub specjalnej procedury ustawodawczej, z udziałem legislatora - Parlamentu Europejskiego i Rady albo samej Rady.

Aby przyspieszyć prace nad ujednolicaniem aktów prawnych w 1994 r., w dwa lata po szczycie Rady Europejskiej w Edynburgu, Parlament Europejski, Rada i Komisja zawarły wspomniane powyżej porozumienie międzyinstytucjonalne dotyczące szybszej metody pracy nad urzędową kodyfikacją tekstów prawnych. Na mocy tego porozumienia trzy instytucje zgodziły się na przyjmowanie tekstów jednolitych w drodze przyspieszonej procedury ustawodawczej, tak aby w możliwie najszybszy sposób udostępnić kompletne akty prawne. Przyspieszona procedura ma polegać m.in. na prowadzeniu prac nad wnioskami Komisji tylko w ramach jednego Komitetu w Parlamencie i jednej grupy w Radzie.

Zgodnie z pkt. 6. wspomnianego porozumienia, w przypadku prac nad ujednoliceniem danego aktu prawnego tzw. ograniczeniem prawnym (limite juridique) jest treść wniosku Komisji, który nie może wprowadzać do tekstu jednolitego tzw. zmian merytorycznych: dodatkowe operacje możliwe w procesie ujednolicania aktów prawnych nie mogą obejmować żadnych zmian wpływających na treść przepisów prawnych, poza zmianami wprowadzonymi aktami podlegającymi ujednoliceniu. Zapis dotyczący niewprowadzania zmian merytorycznych do istniejących tekstów skierowany jest do wszystkich trzech instytucji.

Na mocy postanowień porozumienia Komisja zobowiązała się, że przygotowywane przez nią wnioski ustawodawcze nie będą wykraczały poza wprowadzenie zmian wynikających z istniejących już aktów zmieniających akt pierwotny, zmiany techniczne i nie będą zawierały odrębnych przepisów wprowadzających nowe normy prawne lub zmieniające co do istoty przepisy zawarte $\mathrm{w}$ akcie ujednolicanym. Analogiczne zobowiązanie dotyczyło Parlamentu i Rady, które zobowiązały się do niewprowadzania zmian merytorycznych do wniosku przygotowywanego przez Komisję. Zgodnie z pkt. 8. porozumienia w przypadku, gdy w trakcie prac ustawodawczych nad tekstem jednolitym danego aktu konieczne okaże się wykroczenie poza ramy zwykłego ujednolicenia i wprowadzenie do aktu zmian merytorycznych wpływających na treść norm prawnych, Komisja przedłoży odpowiedni odrębny wniosek lub większą liczbę wniosków ustawodawczych, zawierających odpowiednie zmiany merytoryczne dotychczasowych przepisów, które to wnioski będą przedmiotem prac w ramach normalnej procedury ustawodawczej. Dodatkowo deklaracja trzech instytucji dołączona do porozumienia zawiera zapis, że w przypadku konieczności 
wprowadzenia zmian merytorycznych mających wpływ na istotę przepisów prawnych, do Komisji będzie należał wybór odpowiedniego środka: przedłożenia wniosku ustawodawczego dotyczącego przekształcenia aktu albo przedłożenia autonomicznego wniosku ustawodawczego.

Odrębnym przypadkiem jest sporządzanie tekstów jednolitych aktów prawnych Komisji, a zatem przyjmowanych poza procedurą ustawodawczą z udziałem Parlamentu i Rady. Ten rodzaj prac pozostaje poza zakresem porozumienia międzyinstytucjonalnego, a procedura jest mniej skomplikowana. Tekst jednolity aktu prawnego musi być jednak w tym przypadku przyjęty w drodze odpowiedniej procedury stosowanej przez Komisję, obecnie procedury doradczej lub procedury sprawdzającej zgodnie z postanowieniami rozporządzenia Parlamentu Europejskiego i Rady (UE) nr 182/2011 z dnia 16 lutego 2011 r. ustanawiającego przepisy i zasady ogólne dotyczące trybu kontroli przez państwa członkowskie wykonywania uprawnień wykonawczych przez Komisję. ${ }^{12} \mathrm{~W}$ przypadku sporządzania tekstów jednolitych aktów prawnych Komisji za proces ujednolicenia prawodawstwa z danej dziedziny odpowiedzialna jest odpowiednia Dyrekcja Generalna, wspierana przez Służbę Prawną Komisji.

Ujednolicanie aktów prawnych przyczynia się do faktycznego zredukowania objętości prawodawstwa i zmniejszenia liczby obowiązujących aktów prawnych z jednoczesnym utrzymaniem w mocy przepisów prawnych z danej dziedziny, które zostają ujęte w ramy jednego nowego aktu prawnego. Proces ujednolicania prawa Unii rozpoczął się pod koniec lat 90 . XX w. ${ }^{13}$ Od czasu zawarcia porozumienia międzyinstytucjonalnego w 1994 r. do 2001 r. uchwalono 27 jednolitych tekstów aktów prawnych, które zastąpiły 280 aktów prawnych. ${ }^{14}$

Ujednolicenie w systemie prawa europejskiego różni się od procesu systematyzacji prawa o tej samej nazwie funkcjonującego na gruncie prawa polskiego, gdzie tekst jednolity grupuje wprawdzie akt pierwotny i późniejsze akty nowelizujące, nie ma jednak wpływu na moc obowiązującą aktów włączonych do tekstu jednolitego i nie zastępuje tekstu pierwotnego. ${ }^{15} \mathrm{~W}$ związku z tym ujednolicenie na gruncie prawa polskiego bardziej odpowiada procesowi konsolidacji prowadzonej na gruncie prawa Unii, choć niewątpliwie jest procedurą bardziej sformalizowaną - w Polsce tekst jednolity sporządzany jest w większości przypadków na podstawie upoważnienia przewidzianego $\mathrm{w}$ ustawie $\mathrm{i}$ jest przedmiotem obwieszczenia $\mathrm{w}$ dzienniku urzędowym, w którym opublikowano akt pierwotny. Wersja skonsolidowana

Dz.U. L 55 z 28.2.2011, s. 13.

Szczegółowe zasady, przewidywane skutki i program procesu ujednolicenia prawodawstwa wspólnotowego znajdują się w komunikacie Komisji do Parlamentu Europejskiego i Rady: Codification of the Aquis communautaire (Ujednolicanie prawa wspólnotowego), COM(2001) 645 wersja ostateczna.

Zob. ibidem, s. 3.

Szerzej na temat statusu tekstu jednolitego w prawie polskim por. M. Laskowska, Z. Wrona (red.), materiały z konferencji nt. Tekst jednolity ustawy wobec orzeczeń Trybunału Konstytucyjnego, Warszawa 2013, s. 15-53. 
aktu prawnego Unii nie podlega natomiast formalnej publikacji, a jest automatycznie umieszczana w bazie aktów prawnych EUR-Lex, na stronie mającej charakter swoistej metryki ustawy, na której znajduje się tekst pierwotnie uchwalony, teksty aktów zmieniających i pozostałe informacje dotyczące danego aktu prawnego. Na gruncie prawa polskiego brak jest odpowiedników typowej dla prawa Unii techniki ujednolicenia aktów prawnych i techniki przekształcenia, która zostanie omówiona poniżej.

Procesu ujednolicania dorobku prawnego Unii nie należy również mylić z charakterystyczną dla wielu europejskich porządków prawnych, szczególnie dla prawa francuskiego, kodyfikacją polegającą na grupowaniu aktów prawnych regulujących daną dziedzinę w kompleksowe tematyczne kodeksy. ${ }^{16}$

\section{Przekształcenie aktu prawnego}

Instrumentem $\mathrm{w}$ większym stopniu ingerującym $\mathrm{w}$ tekst aktu prawnego niż ujednolicenie jest jego przekształcenie (ang. recast, fr. refonte), które polega na zespoleniu w jednym tekście: tekstu aktu pierwotnego, zmian wprowadzonych przez akty zmieniające oraz wprowadzeniu, w razie konieczności, tzw. zmian merytorycznych, które mogą polegać na przeformułowaniu istniejących przepisów, ich zmianie lub dodaniu nowych przepisów, co nie jest możliwe w przypadku sporządzania tekstu jednolitego. To właśnie zdefiniowany z porozumieniu międzyinstytucjonalnym z 2001 r. dotyczącym techniki przekształcenia termin ,zmiana merytoryczna” jest zasadniczym elementem odróżniającym teksty jednolite aktów prawnych od tekstów przekształconych.

Technika przekształcenia jest powszechnie stosowana od czasu zawarcia porozumienia międzyinstytucjonalnego przez Parlament Europejski, Komisję i Radę w 2001 r. w sprawie bardziej uporządkowanego wykorzystania techniki przekształcania aktów prawnych. Punkt 2 porozumienia definiuje przekształcenie jako ,proces polegający na przyjęciu nowego aktu prawnego, który łączy, w ramach jednego tekstu, zarówno zmiany merytoryczne wprowadzane przez nowy akt do wcześniejszego aktu, jak i niezmienione postanowienia wcześniejszego aktu; nowy akt prawny zastępuje i uchyla akt wcześniejszy". Deklaracja dołączona do porozumienia wprowadza rozróżnienie na ,przekształcenie pionowe” i ,przekształcenie poziome". Pierwsza technika, podobnie jak w przypadku ujednolicenia, polega na zastąpieniu nowym aktem jednego aktu pierwotnego i aktów go zmieniających, druga zaś na zastąpieniu przez nowy akt prawny większej liczby aktów pierwotnych i aktów je zmieniających, które do tej pory równolegle regulowały daną dziedzinę. ${ }^{17}$ 
Wybrane metody systematyzacji prawodawstwa Unii Europejskiej z uwzględnieniem...

Zgodnie z pkt. 3. porozumienia z 2001 r., celem przekształcenia jest właśnie wprowadzenie zmian merytorycznych do tekstu, które zdefiniowano jako „wszelkie zmiany mające wpływ na treść wcześniejszego aktu, w odróżnieniu od zmian czysto formalnych lub redakcyjnych". Obok przepisów, do których wprowadzono zmiany merytoryczne tekst przekształcony zawiera zdefiniowane w pkt. 4. tiret pierwsze porozumienia tzw. przepisy niezmienione, czyli ,przepisy wcześniejszego aktu, które nie zostały poddane zmianom merytorycznym, pomimo że mogły zostać poddane zmianom czysto formalnym lub redakcyjnym”. Wniosek ustawodawczy Komisji dotyczący przekształcenia aktu prawnego zawiera zatem w sobie propozycje trzech działań, które ma podjąć ustawodawca: zmiany merytoryczne aktu wcześniejszego, zmiany typowe dla procesu ujednolicania aktów oraz uchylenie aktów wcześniejszych i zastąpienie ich nowym aktem.

Wniosek dotyczący przekształcenia tekstu przedkładany jest przez Komisję Parlamentowi Europejskiemu oraz Radzie i podlega rozpatrzeniu w ramach procedury ustawodawczej przewidzianej dla danej dziedziny przez TFUE, z tą różnicą, że w przypadku przekształcenia nie ma zastosowania procedura uproszczona. Akt przekształcony zawiera odrębne motywy uzasadniające zarówno konieczność zastosowania techniki przekształcenia w ogóle, jak i każdą merytoryczną zmianę przepisów, a także wskazujące przepisy niezmienione. Aby zapewnić zgodność z zasadą pewności prawa, akt przekształcony musi zawierać motyw wskazujący, że nowy akt prawny stanowi przekształcenie aktu wcześniejszego oraz zawierać w artykule uchylającym dotychczasowy akt stwierdzenie, że odesłania do aktu uchylonego należy odczytywać jako odesłania do nowego aktu zgodnie z dołączoną do niego w załączniku tabelą korelacji. Jeśli przekształcenie dotyczy dyrektywy, dodatkowym ważnym elementem jest ustanowienie obowiązku transpozycji nowych lub zmienionych przepisów do prawa krajowego oraz wskazanie, że obowiązek transpozycji dotyczy wyłącznie tych przepisów, jako że przepisy niezmienione są lub powinny były zostać przeniesione wcześniej na grunt prawa krajowego.

Prace nad projektem aktu przekształconego prowadzone są w ramach grupy konsultacyjnej służb prawnych Parlamentu, Rady i Komisji, która przekazuje instytucjom projekt aktu ze wskazaniem, że nie zawiera on dodatkowych zmian merytorycznych poza tymi zaproponowanymi przez Komisję. Podobnie jak w przypadku ujednolicania aktu ograniczeniem prawnym jest tu treść wniosku Komisji. Chociaż w przypadku przekształcenia wniosek Komisji może sugerować wprowadzenie zmian merytorycznych, to Parlament i Rada są nim związane i nie mogą wprowadzać żadnych dodatkowych zmian. Jeśli w trakcie procesu ustawodawczego okaże się, że takie dodatkowe zmiany są wymagane, zgodnie z pkt. 8. porozumienia 
z 2001 r. zmiany te będą musiały zostać ujęte w nowym wniosku ustawodawczym i przyjęte w formie odrębnego aktu.

Przekształcenie aktów prawnych umożliwia znaczne uproszczenie wtórnego ustawodawstwa Unii. W przypadku tego instrumentu częściej niż w przypadku ujednolicania aktów stosowane jest wspomniane wyżej działanie „poziome”, polegające na skupieniu w jednym akcie kilku aktów wcześniejszych oraz aktów je zmieniających, co pozwala w dużym stopniu zredukować objętość prawodawstwa. Do chwili obecnej ustawodawca uchwalił ponad 50 aktów prawnych, będących wynikiem przekształcenia zaproponowanego przez Komisję.

\section{Systematyzacja unijnego prawodawstwa rolnego}

Działania zmierzające do uproszczenia ustawodawstwa mają szczególne znaczenie dla unijnego prawodawstwa rolnego, kompleksowej i podlegającej częstym zmianom dziedziny prawa. W ciągu ostatniej dekady Komisja była inicjatorem działań zmierzających do usystematyzowania unijnego prawa rolnego, które mają poprawić czytelność tekstów prawnych, zmniejszyć ich ilość oraz zredukować obciążenia administracyjne nałożone zarówno na samych beneficjentów programów finansowanych ze środków Unii, jak i na krajowe instytucje wdrażające.

Podstawą procesu uproszczenia prawodawstwa wspólnotowego jest założenie, że regulacje prawnorolne i mechanizmy wybrane do wdrażania określonych działań nie powinny być bardziej skomplikowane niż cel, jaki mają osiągnąć. ${ }^{18}$ Od strony formalnej na proces uproszczenia unijnego prawa rolnego składają się cztery elementy ${ }^{19}$ : wewnętrzne wytyczne dotyczące redagowania tekstów prawnych w Dyrekcji Generalnej ds. Rolnictwa i Wspierania Rozwoju Obszarów Wiejskich, nieurzędowa konsolidacja, zmniejszenie liczby obowiązujących rozporządzeń oraz uproszczenie mechanizmów handlu.

Wewnętrzne wytyczne skierowane są do Dyrekcji Generalnej ds. Rolnictwa i Wspierania Rozwoju Obszarów Wiejskich. Zgodnie z nimi poszczególne działy Dyrekcji mają zalecenie zapewnienia, aby każdy nowo przygotowywany akt prawny został sporządzony w sposób prosty i jasny, zarówno w odniesieniu do formy i struktury tekstu, jak i do samego formułowania praw i obowiązków podmiotów.

Dodatkowo, od 1999 r. dokonywana jest bieżąca nieurzędowa konsolidacja wtórnego prawodawstwa rolnego, a skonsolidowane teksty aktów prawnych dostępne są we wszystkich językach urzędowych Unii w bazie aktów prawnych EURLex. Ze względu na liczbę aktów prawnych w dziedzinie rolnictwa, ich złożoność

Zob. sprawozdanie Komisji do Parlamentu Europejskiego i Rady: Simplification of agricultural legislation (Uproszczenie prawodawstwa rolnego), COM(2001)48 wersja ostateczna.

19 Zob. sprawozdanie Komisji dla Rady Europejskiej w Sztokholmie Improving and simplifying the regulatory environment (Poprawa i uproszczenie otoczenia regulacyjnego), COM(2001) 130 wersja ostateczna, s. 16. 
i częstotliwość zmian, jakim podlegają, proces konsolidacji ma ułatwić zainteresowanym dostęp do prawodawstwa rolnego poprzez zapewnienie kompletnego tekstu odzwierciedlającego aktualny stan prawny w danej dziedzinie. Nieformalna konsolidacja unijnego prawodawstwa rolnego objęła do końca 2000 r. około 500 aktów prawnych. ${ }^{20}$ Przykładowo rozporządzenie Rady (WE) nr 1234/2007 z dnia 22 października 2007 r. ustanawiające wspólną organizację rynków rolnych oraz przepisy szczegółowe dotyczące niektórych produktów rolnych (rozporządzenie o jednolitej wspólnej organizacji rynków $)^{21}$ w sześcioletnim okresie obowiązywania zostało zmienione kilkadziesiąt razy oraz podlegało konsolidacji 13 razy.

Zmniejszenie liczby rozporządzeń prawnorolnych jest kolejnym działaniem o widocznych rezultatach. W latach 80 . XX w. istniało wiele odrębnych wspólnych organizacji rynków rolnych, z których każda obejmowała inny sektor rynku (sektor wina, cukru, owoców i warzyw itp.) i rządzona była odmiennymi regułami. W ramach Agendy 2000 wprowadzono szereg uproszczeń do obowiązującego wówczas prawodawstwa rolnego, polegających na zmniejszeniu liczby aktów prawnych poprzez ich uchylenie i zastąpienie. Na pierwszym etapie prac akty prawne regulujące organizację rynku rolnego $\mathrm{w}$ zakresie danego sektora zostały zastąpione jednym aktem. Przykładowo w sektorze wina, będącym najbardziej rozbudowanym pod względem regulacyjnym, jeden akt prawny tj. rozporządzenie Rady (WE) nr 1493/1999 z dnia 17 maja 1999 r. w sprawie wspólnej organizacji rynku wina ${ }^{22}$ zastąpił dotychczas obowiązujące 23 akty prawne, a cztery rozporządzenia wykonawcze Komisji ${ }^{23}$ zastąpiły dotychczas obowiązujących 36 wykonawczych aktów prawnych. Podobnym działaniom podlegało prawodawstwo z obszaru pozostałych wspólnych organizacji rynków rolnych. W następnej kolejności wszystkich odrębnych 21 wspólnych organizacji rynków rolnych zostało zgrupowanych i ujętych w jednym akcie prawnym, tj. wspomnianym wyżej rozporządzeniu Rady (WE) nr 1234/2007. Umożliwiło to uchylenie 86 aktów prawnych Rady i zastąpienie 1080 artykułów ok. 350 artykułami. $^{24}$

Podejście to zostało utrzymane także na gruncie nowego rozporządzenia Parlamentu Europejskiego i Rady (UE) nr 1308/2013 z dnia 17 grudnia 2013 r. ustanawiającego wspólną organizację rynków produktów rolnych oraz uchylającego rozporządzenia Rady (EWG) nr 922/72, (EWG) nr 234/79, (WE) nr 1037/2001 i (WE) nr 1234/2007, ${ }^{25} \mathrm{w}$ zakres którego wchodzą wszystkie produkty wymienione w załączniku I do TFUE zgrupowane w 24 sektorach wymienionych w art. 1 ust. 2 tego

Por. sprawozdanie Komisji do Parlamentu Europejskiego i Rady Simplification of agricultural legislation (Uproszczenie prawodawstwa rolnego), COM(2001) 48 wersja ostateczna, s. 5.

Dz. U. L 299 z 16.11.2007, s. 1.

Dz.U. L 179 z 14.7.1999, s. 1.

Rozporządzenia Komisji (WE) nr 1227/2000, (WE) nr 1623/2000, (WE) nr 1622/2000, (WE) nr 1607/2000.

Por. informacje na stronie Dyrekcji Generalnej ds. Rolnictwa i Rozwoju Obszarów Wiejskich, http://ec.europa.eu/ agriculture/simplification/index_en.htm

Dz.U. L 347 z 20.12.2013, s. 671 . 
rozporządzenia. Kwestie szczegółowe dotyczące danego sektora są regulowane w drodze przyjmowanych przez Komisję aktów wykonawczych albo aktów delegowanych.

Podobnej systematyzacji poddany został drugi filar wspólnej polityki rolnej, dotyczący wspierania rozwoju obszarów wiejskich. W początkowej fazie funkcjonowania polityki wspierania rozwoju obszarów wiejskich, każdy z instrumentów regulowany był odrębnym rozporządzeniem. Systematyzacja i ujęcie w ramy jednego aktu prawnego nastąpiła w 2005 r., poprzez przyjęcie rozporządzenia Rady (WE) nr 1698/2005 z dnia 20 września 2005 r. w sprawie wsparcia rozwoju obszarów wiejskich przez Europejski Fundusz Rolny na rzecz Rozwoju Obszarów Wiejskich (EFRROW), ${ }^{26}$ które zgrupowało wszystkie instrumenty wspierania rozwoju obszarów wiejskich w cztery osie tematyczne. Od 1 stycznia 2014 r. podstawą prawną instrumentów wspierania rozwoju obszarów wiejskich jest rozporządzenie Parlamentu Europejskiego i Rady (UE) nr 1305/2013 z dnia 17 grudnia 2013 r. w sprawie wsparcia rozwoju obszarów wiejskich przez Europejski Fundusz Rolny na rzecz Rozwoju Obszarów Wiejskich (EFRROW) i uchylające rozporządzenie Rady (WE) nr 1698/2005, ${ }^{27}$ którego tytuł III zawiera prawne wymogi dotyczące poszczególnych instrumentów wspierania rozwoju obszarów wiejskich.

Uproszczone horyzontalne ramy prawne systemu dopłat bezpośrednich wprowadziło rozporządzenie Rady (WE) nr 1782/2003 z dnia 29 września 2003 r., ustanawiające wspólne zasady dla systemów wsparcia bezpośredniego w ramach wspólnej polityki rolnej i ustanawiające określone systemy wsparcia dla rolników. ${ }^{28}$ Ten akt prawny zapoczątkował system jednolitej płatności i wspólne zasady dotyczące dopłat bezpośrednich obejmujące większą liczbę sektorów. Systematykę tę przejęło rozporządzenie (WE) nr 73/2009 z dnia 19 stycznia 2009 r. ustanawiające wspólne zasady dla systemów wsparcia bezpośredniego dla rolników w ramach wspólnej polityki rolnej i ustanawiające określone systemy wsparcia dla rolników, ${ }^{29}$ a także obecnie obowiązujące rozporządzenie Parlamentu Europejskiego i Rady (UE) nr 1307/2013 z dnia 17 grudnia 2013 r. ustanawiające przepisy dotyczące płatności bezpośrednich dla rolników na podstawie systemów wsparcia w ramach wspólnej polityki rolnej oraz uchylające rozporządzenie Rady (WE) nr 637/2008 i rozporządzenie Rady (WE) nr 73/2009. ${ }^{30}$

W wyniku wymienionych działań systematyzujących wspólna polityka rolna regulowana jest obecnie czterema podstawowymi aktami prawnymi: trzema wymienionymi powyżej rozporządzeniami nr 1305/2013, nr 1307/2013 i nr 1308/2013 
oraz rozporządzeniem Parlamentu Europejskiego i Rady (UE) nr 1306/2013 z dnia 17 grudnia 2013 w sprawie finansowania wspólnej polityki rolnej, zarządzania nią i monitorowania, ${ }^{31}$ które jest aktem prawnym o charakterze horyzontalnym. W literaturze pojawiają się nawet poglądy, że usystematyzowanie europejskiego prawa rolnego poprzez ujęcie najważniejszych instrumentów w zaledwie kilku tematycznych aktach prawnych doprowadziło do powstania kodeksu europejskiego prawa rolnego. ${ }^{32}$

Czwartym i ostatnim elementem uproszczenia unijnego prawodawstwa rolnego jest dostosowanie mechanizmów dotyczących handlu produktami rolnymi poprzez zmniejszenie wymogów dla pozwoleń na wywóz z 500 do 65 i utrzymanie jedynie 43 wymogów dla pozwoleń na przywóz. ${ }^{33}$ Tego rodzaju horyzontalne działania systematyzujące prawodawstwo objęły także inne dziedziny wspólnej polityki rolnej, ${ }^{34}$ takie jak promocja produktów rolnych, nowe wytyczne dotyczące pomocy państwowej czy zintegrowany system IACS. ${ }^{35}$

\section{Uwagi końcowe}

Przedstawione powyżej przykładowe instrumenty systematyzacji dorobku prawnego Unii polegają zarówno na upraszczaniu samej formy aktów prawnych, jak i treści przepisów oraz zawartych w nich norm prawnych. Do chwili obecnej dokonano znacznego zredukowania liczby aktów prawnych, co czyni prawodawstwo Unii bardziej przystępnym i ułatwia jego stosowanie. Proces ten będzie kontynuowany w przyszłości zgodnie z nowymi założeniami zawartymi w programie REFIT przewidującym dalsze zmniejszenie obciążeń administracyjnych i uproszczenie wtórnego prawodawstwa Unii za pomocą dodatkowych instrumentów. ${ }^{36}$

Dz.U. L 347 z 20.12.2013, s. 549.

Por. Ferdinando Albisinni, Europejskie prawo rolne po Traktacie z Lizbony pomiędzy interwencją a regulacją - Europejskie kodeksy rolnictwa, „Przegląd Prawa Rolnego” 2011, nr 1(8).

Por. informacje na stronie Dyrekcji Generalnej ds. Rolnictwa i Rozwoju Obszarów Wiejskich, http://ec.europa.eu/ agriculture/simplification/index_en.htm

Por. sprawozdanie Komisji $\operatorname{COM}(2001)$ 48, op. cit., s. 6.

Dodatkowymi instrumentami pozwalającymi na zmniejszenie liczby aktów prawnych są rozporządzenia uchylające akty nieaktualne, zob. np. rozporządzenie Parlamentu Europejskiego i Rady (UE) nr 1229/2011 z dnia 16 listopada 2011 r. w sprawie uchylenia niektórych nieaktualnych aktów prawnych Rady w dziedzinie wspólnej polityki rolnej, Dz.U. L 326 z 8.12.2011, s. 18 oraz rozporządzenie Parlamentu Europejskiego i Rady (UE) nr 1230/2011 z dnia 16 listopada 2011 r. w sprawie uchylenia niektórych nieaktualnych aktów prawnych Rady, Dz.U. L 326 z 8.12.2011, s. 21 .

Zob. komunikaty Komisji: Sprawność regulacyjna UE, COM(2012) 746 wersja ostateczna oraz Sprawność i wydajność regulacyjna (REFIT): Wyniki oraz dalsze kroki, COM(2013) 685 wersja ostateczna. 
CERTAIN METHODS OF SIMPLIFICATION OF THE EUROPEAN UNION LAW WITH FOCUS ON THE AGRICULTURAL LEGISLATION

Key words: simplification of the European Union legislation, consolidation, codification, recast, agricultural legislation

This paper refers to certain aspects of the process of simplification of the European Union legislation. It focuses on the three main methods of editorial and substantial intervention in the text of a Union legal act, i.e. consolidation, codification and recast.

Those three conceptions, their purpose and differences between them in terms of the procedure applied and the legal and practical consequences for the Union law are elaborated. Interdependence of those three methods is explained. The first step of the technical simplification of the Union law is the informal consolidation of the text of a legal act which forms the basis for the formal codification work at a later stage, which in turn is the basis for recasting of a legal act.

The importance and results of the law simplification process in the three main pillars of the common agricultural policy: the common organisation of the markets, direct payments and rural development are demonstrated. 